ROCZNIKI PEDAGOGICZNE

Tom 11(47), numer 2 - 2019

DOI: http://dx.doi.org/10.18290/rped.2019.11.2-2

KINGA KUSZAK

\title{
ROZWIJANIE OSOBOWOŚCI I PASJI NAUCZYCIELI W PŁYNNEJ RZECZYWISTOŚCI XXI WIEKU - POSZUKIWANIE ROZWIAZZAŃ
}

\section{WPROWADZENIE}

Wybitny pedagog Wincenty Okoń pisał, iż nauczyciel to ten, który kształci, wychowuje i rozwija znajdujących się pod jego opieką uczniów (dzieci, młodzież, dorosłych). Powodzenie tej pracy, jak zaznaczył, zależy od czterech elementów: uczniów, programu, zewnętrznych warunków i od samego nauczyciela. (Okoń, 1992, s. 135). W niniejszym opracowaniu spośród wymienionych przez niego czterech elementów interesuje mnie jeden - osoba nauczyciela, jego osobowość, na którą składają się specyficznie zorganizowane cechy intelektualne, emocjonalne, temperamentalne i wolicjonalne. Zanim przejdę do głównego wątku moich rozważań, wspomnę w kilku zdaniach o elementach natury zewnętrznej, które determinują warunki życia i pracy współczesnych nauczycieli. Oczywistym wydaje się być stwierdzenie, że żyjemy w rzeczywistości nieustannych zmian. Jak ujął to Zygmunt Bauman - żyjemy w rzeczywistości płynnej. Płynność, ciekłość, zmienność, brak stałości, to określenia charakteryzujące współczesność. Te zmiany determinują nasze życie. W istotny sposób wpływają na to, jak swoje powołanie realizują współcześni nauczyciele. Jak pisze Z. Bauman: „,społeczeństwo płynnej nowoczesności to społeczeństwo, w którym warunki działania ulegają zmianie, zanim sposoby działania zdążą zakrzepnąć w zwyczajowych i rutynowych formach" (Bauman, 2007, s. 5). Teresa Hejnicka-Bezwińska dodaje, iż nieciągłość i niespodziewaność oraz głębia i radykalność przemian, które obejmują różne dziedziny życia społecznego pozwalają mówić o rzeczywistości, w której żyjemy

Dr hab. KINGA KuSZAK, prof. UAM - Wydział Studiów Edukacyjnych, Uniwersytet im. Adama Mickiewicza w Poznaniu; e-mail: kingak@ amu.edu.pl 
w kategoriach traumy kulturowej (Hejnicka-Bezwińska, 2008, s. 186), zaś „okoliczności działania i podporządkowane im strategie postępowania starzeją się szybko i ulegają przedawnieniu, zanim ktokolwiek zdoła je gruntownie poznać. Czerpanie wiedzy z doświadczenia i odwoływanie się do strategii i taktyk, które sprawdziły się w przeszłości, jest zatem nieroztropne, bo dawne testy nie uwzględniały gwałtownych i na ogół nieprzewidywanych (albo po prostu nieprzewidywalnych) zmian okoliczności" (Bauman, 2007, s. 5-6). Z. Bauman dodaje dalej, że prognozowanie przyszłych tendencji na podstawie przeszłych wydarzeń jest jeszcze bardziej ryzykowne. Jego zdaniem ,większość zmiennych w równaniach stanowią niewiadome, a żadne szacunki dotyczące przyszłości nie zasługują na pełne zaufanie" (Bauman, 2007, s. 6). Życie w płynnej rzeczywistości to zatem życie w niepewności, niewiedzy, w warunkach ciągłego niepokoju. Otto Speck zaznacza, że w tej sytuacji liczy się to, „,zy jednostka potrafi reagować na ciągle zmieniające się sytuacje i spełniać coraz to nowe żądania dotyczące norm, czy radzi sobie $w$ jeszcze nieopisanych i niesklasyfikowanych okolicznościach, czy nie traci głowy, gdy w zakresie norm nie ma jasnej podstawy działania" (Speck, 2005, s. 67-68). Konieczność sprostania różnym, zmieniającym się i trudnym do przewidzenia oczekiwaniom prowadzi do wypracowania przez jednostki zróżnicowanych sposobów radzenia sobie w dynamicznej rzeczywistości i w konsekwencji do powstania różnych stylów życia. Teresa Hejnicka-Bezwińska zaznacza, że zróżnicowane wzory osobowe późnej nowoczesności łączy niekonsekwencja, epizodyczność, niespójność, fragmentaryczność, a źródłem satysfakcji życiowej staje się gromadzenie przez jednostki różnego typu dóbr materialnych, wrażeń, doświadczeń itp. (Hejnicka-Bezwińska, 2008, s. 191). Stałe kontakty międzyludzkie przekształcają się w relacje typowe dla rojów, które „schodzą się, rozchodzą i zbierają na powrót od jednej okazji do drugiej, powodowane różnymi, zawsze zmiennymi zainteresowaniami i przyciągane przez coraz to nowe, a $\mathrm{z}$ reguły ruchome cele" (Bauman, 2009, s. 84). Takie roje tworzą też nauczyciele zogniskowani zaledwie na krótką chwilę wokół jakiegoś zadania, celu, wspólnie realizowanego przedsięwzięcia, warsztatu, a „uwodzicielska moc ruchomych celów z zasady wystarcza, żeby wprowadzić rój w ruch" (Bauman, 2009, s. 85). Znajdują się w ciągłym ruchu poszukując nowych metod, lepszych sposobów pracy z klasą, z uczniem. Przechodzą przez kolejne kursy i szkolenia, kolekcjonując zaświadczenia i certyfikaty, gdyż „w roju nie ma specjalistów [...]. Każdy element jest sam sobie sterem, żeglarzem i okrętem i musi posiąść komplet kwalifikacji i narzędzi koniecznych do wypełnienia całego zadania" (Bauman, 2009, s. 85). Koncentrując się na zdobywaniu kolejnych kwalifikacji i dyplomów, 
goniąc za nowinkami, członkowie roju tracą często z oczu zasadniczy cel, jakim jest tworzenie uczniom warunków dla ich indywidualnego rozwoju i osobowego wzrastania. Nie mają czasu i siły, by skoncentrować swoją uwagę na osobach, z którymi pracują i współpracują, gdyż nieustannie coś ich rozprasza i popycha do podejmowania kolejnych pospiesznie realizowanych zadań. „Elementy wypadające z peletonu podczas lotu po prostu „zabłądziły”, „,zgubiły się” albo „wypadły z szyku [...], ale życie samotnych indywidualistów rzadko trwa długo, ponieważ szansa znalezienia realistycznego celu własnym sumptem jest dużo mniejsza, niż wówczas, kiedy leci się w roju, a gdy się podąży za urojonym, bezużytecznym lub niebezpiecznym celem ryzyko zguby wielokrotnie rośnie" (Bauman, 2009, s. 86). Tak jest w przypadku nauczycieli próbujących nadążyć za zamianami w systemie oświaty i poza nim. W ten sposób, będąc w nieustannym ruchu i próbując utrzymać się w peletonie, nauczyciele tracą z oczu to, co najważniejsze - potrzeby swoich uczniów i własne autentyczne pasje zawodowe, które były zasadniczym bodźcem do podjęcia studiów nauczycielskich.

\section{WYBRANE CECHY OSOBOWOŚCI NAUCZYCIELA W XXI WIEKU W PERSPEKTYWIE ZADAŃ NOWOCZESNEJ SZKOŁY}

Magdalena Środa zaznacza, że nowoczesna szkoła powinna:

- przygotowywać uczniów do aktywnego udziału w życiu intelektualnym, społecznym, kulturowym, politycznym i ekonomicznym nowoczesnych krajów;

- dostosowywać się do rozwoju nauk, środków komunikacji, do wymagań rynków pracy, do potrzeb demokratycznego społeczeństwa i wymogów obywatelskiego zaangażowania;

- być wrażliwa na cywilizacyjne zmiany (techniczne, społeczne, kulturowe);

- dostarczać nowoczesnej wiedzy, ale również umiejętności jej selekcji, ewaluacji, doboru, gromadzenia, przekształcania;

- szanować wolność uczniów i uczennic oraz ich autonomię, troszczyć się o równe traktowanie wszystkich;

- wychowywać w duchu dyspozycji i postaw niezbędnych do bycia empatycznym, zaangażowanym, prawym, autonomicznym, odpowiedzialnym członkiem społeczności (Środa M., https://www.kongreskobiet.pl/Content/uploaded/files/ CAiE\%20i\%20Media/02_Edukacja\%20XXI-Raport.pdf - [dostęp: 7.01.2019]).

$\mathrm{Z}$ całą pewnością zadaniem szkoły w XXI wieku jest zorientowanie działań na stymulowanie i doskonalenie u uczniów takich umiejętności, które będą im 
potrzebne w przyszłym życiu. Jej zadaniem jest więc stworzyć młodym ludziom takie warunki, by rozwijali i doskonalili kompetencje niezbędne do radzenia sobie w zmieniającej się „płynnej” rzeczywistości. Szkoła powinna być zatem nastawiona na wspieranie u uczniów umiejętności radzenia sobie ze zmianami, których doświadczą i będą doświadczać w całym życiu pamiętając, że ,życie rzadko daje się uporządkować na wzór książki kucharskiej, pełnej recept i przepisów" (Bruner, 2010, s. 31). Powinna zatem tworzyć uczniom takie warunki, by ci zamiast opanowywać na pamięć kolejne „recepty” doświadczali tego, jak skutecznie się uczyć i jak myśleć. Tym bardziej, że przecież dzisiejsi uczniowie mają niemal nieograniczony dostęp do informacji. W tej sytuacji zamiast uczenia się na pamięć potrzebują wypracować własne sposoby radzenia sobie z różnej jakości informacjami, nadmiarem danych, ich selekcjonowaniem, porządkowaniem, ewaluacją oraz wykorzystywaniem w praktycznym działaniu. Jak podkreśla Jerome Brunner „edukacja, zawężając zakres poszukiwań interpretacyjnych, powoduje redukcję właściwej kulturze zdolności adaptacji do zmiany. A we współczesnym świecie zmiana jest normą" (Bruner, 2010, s. 32). Tak więc młodzi ludzie powinni umieć w sposób elastyczny radzić sobie ze zmianami. Bezsprzecznie istotne jest wobec tego stymulowanie myślenia, które jest - jak to ujmuje Bartosz Brożek - swoistą grą między teoretyzowaniem i symulacją mentalną, czyli konstruowaniem abstrakcyjnych teorii i wyobrażaniem sobie konkretnych sytuacji (Brożek, 2017, s. 6-7). Młodzi ludzie muszą stać się krytyczni wobec tego, co ich otacza, analizować fakty, wybierać spośród różnych przedstawianych im alternatyw, przewidywać konsekwencje swoich decyzji i wyborów. Umiejętność selekcjonowania danych jest istotna również dlatego, że w dzisiejszych czasach ujawnia się znaczne rozproszenie między wiedzą formalną a codzienną praktyką. Poziom nauczania jest zdecydowanie wyższy, niż w przeszłości, ale ta formalizacja kształcenia nie idzie w parze $\mathrm{z}$ umiejętnościami, ze sztuką zarządzania konkretami, która przekształca wiedzę szkolną w praktykę (Bauman, Leonicini, 2018, s. 98). Nie bez znaczenia w niestałym świecie jest rozwijanie u każdej jednostki szacunku dla niej samej, gdyż „szacunek jest niezbędny, by rozwijać się i dojrzewać" (Dryden, Vos, 2003, s. 107), by zmagać się z codziennością, w której trzeba szybko podejmować decyzje i ponosić ich konsekwencje. Szacunek dla ucznia ciągle jest sprawą marginalizowaną, choć powszechnie jest wiadomo, że uczniowie uczą się tego, czego doświadczają i wiele osób potrafi powtórzyć za Dorothy Law Nolte, że „dziecko krytykowane uczy się potępiać, dziecko otoczone wrogością, uczy się agresji, dziecko żyjące w strachu uczy się lękliwości, dziecko doświadczające litości uczy się rozczulać nad sobą, dziecko 
wyśmiewane uczy się nieśmiałości, dziecko otoczone zazdrością uczy się zawiści, dziecko zawstydzane uczy się poczucia winy..." (za: Dryden, Vos, 2003, s. 104). W tym miejscu nie sposób zatem nie przywołać niezmiennie aktualnych słów Janusza Korczaka, który w następujący sposób napominał dorosłych: „przystrojeni w purpurę lat, jakże często narzucamy bezmyślne, bezkrytyczne, niewykonalne przepisy" (Korczak, 2017, s. 28). Wobec tych bezdusznych przepisów podkreślał dalej J. Korczak - dziecko staje zdumione. Łatwo tracimy z oczu fakt, że dziecko otoczone szacunkiem uczy się szacunku dla siebie i innych. Szacunkiem należy zatem darzyć prawo dziecka do poznania tego, co je interesuje i pociąga do wyboru i decyzji, choć mogą być niezgodne z zamysłem dorosłego.

W XXI wieku potrzeba zatem nauczycieli otwartych i elastycznych: elastycznie radzących sobie ze zmianami i różnorodnością: odpowiadających na zróżnicowane i indywidualne potrzeby uczniów, zmieniające się regulacje formalno-prawne, płynne relacje społeczne, zmieniające się możliwości itp. oraz poprzez swoją elastyczność wspierający uczniów w kształtowaniu ich życiowych postaw. Trzeba więc - zauważa Czesław Kupisiewicz - zwrócić uwagę przede wszystkim na predyspozycje i cechy osobowościowe nauczyciela (Kupisiewicz, 2012, s. 223). Wspomniany autor dodaje, że ,predyspozycje i cechy osobowości, notabene różnie przez różnych autorów interpretowane tak co do roli, jak i treści oraz zakresu składających się na nie elementów, poczynając na przykład od „miłości do dusz ludzkich”, a kończąc na „ujmujących właściwościach zewnętrznych”, przesądzają niejednokrotnie o stosunku uczniów do nauki określonego przedmiotu w szkole, a nawet - po jej ukończeniu - o wyborze dalszego kierunku edukacji” (Kupisiewicz, 2012, s. 224). Nie ulega wątpliwości, jak piszą Maria Dudzikowa i Marian Nowak, że pedagodzy z pasją inspirują swoich wychowanków. Pasja takich pedagogów, nauczycieli czy rodziców sprawia, że [...] uczniowie czy w ogóle ludzie zajmują się daną problematyką, a młody człowiek [...] poświęca się określonemu rodzajowi działalności" (Dudzikowa, Nowak, 2015, s. 8). Konsekwencją braku pasji jest przeciętność rezultatów pracy. Zdaniem wspomnianych autorów pasja jest nie tylko wartością przeżywaną (egzystencjalną), jest osobista i niepowtarzalna, to jednak zawsze jest przeżywana w relacji z innymi i wśród innych (Dudzikowa, Nowak, 2015, s. 8). Pasja zasługuje na szacunek, a zatem pielęgnowanie własnych pasji i wspieranie pasji uczniowskich jest przejawem szacunku wobec siebie i tych, których powierzono nauczycielom.

Obserwacja szkolnej rzeczywistości pozwala zauważyć, że pasja nauczyciela, jego zaangażowanie i umiejętność dzielenia się nią z uczniami przyciąga uczniów do nauczyciela i inspiruje młodych ludzi do wartościowych działań. Przywołam 
zatem wybrane przykłady nauczycieli z pasją. Przykład pierwszy: nauczycielpasjonat, który wspólnie z uczniami rok w rok organizuje zbiórkę karmy dla schroniska opiekującego się porzuconymi królikami; przykład drugi: nauczycielka, która potrafi skłonić ich do refleksji nad wojennymi, trudnymi wygnańczo-tułaczymi losami poetów z grupy Skamander, ich dylematami moralnymi, wyborami, których dokonywali; przykład trzeci: nauczycielka, która swoją postawą uruchamia zachowania pomocowo-wolontariackie na rzecz koleżanki znajdującej się w potrzebie; przykład czwarty: nauczycielka, która swoimi zainteresowaniami, doświadczeniem i wiedzą inspiruje uczniów do zainteresowania kulturą, sztuką i tańcem węgierskim, wspólnie z uczniami organizuje „dni węgierskie” w szkole, podczas których uczniowie nie tylko poznają kulturę tego kraju, ale integrują się podczas wspólnie realizowanych celów i zadań z nich wynikających. Nie sposób więc nie zgodzić się z Cz. Kupisiewiczem, podkreślającym, że uczniowie, którzy są zafascynowani osobowością nauczyciela, widzą w nim wzór, który warto naśladować i w konsekwencji przejmują wiele jego pozytywnych cech. Trzeba też dodać, że młodzi ludzie prawdziwie cenią takich autentycznych zaangażowanych nauczycieli z pasją, którzy dzielą się wiedzą i zainteresowaniami dalece wykraczającymi poza ramy programów szkolnych. Na potwierdzenie tej tezy przytoczę dwie uczniowskie wypowiedzi.

\section{Wypowiedź 1.}

„Cenię panią X za taką nieprawdopodobną erudycję, że jest chodzącą encyklopedią i dzieli się z nami wiedzą wykraczającą poza program. Rozmawiamy o Tuwimie i Skamandrytach, na temat Awangardy w literaturze i to nie jest tak, że mamy się nauczyć, że „Słowacki wielkim poetą był”, tylko zastanawiamy się dlaczego tak było, co to spowodowało. Pani cierpi na logoreę, ale chce się tego słuchać. Zaskoczeniem było dla mnie to, że podczas lekcji oglądaliśmy filmy. Ale oglądaliśmy filmy wybitne. To nie była strata czasu. To było wielkie kino" (uczeń LO na temat nauczycielki języka polskiego).

\section{Wypowiedź 2.}

„Cenię pana Y za wiedzę historyczno-społeczną i kulturową. Podczas lekcji WOS-u mamy jednocześnie lekcję historii i kulturoznawstwa. Pan Y to nie jest nauczyciel. My nie mamy z nim takiej relacji nauczyciel-uczeń. Nie ma tej granicy. Wspólnie przekraczamy granice, ale się nawzajem szanujemy. Pan Y jest nam bliski, dla nas ważny, jak przyjaciel. Podczas lekcji często robi dygresje, ale takie na ważne tematy. Uczy nas krytycyzmu w odniesieniu do informacji na- 
pływających do nas ze świata mediów. Pokazuje, jak zachować dystans do tego, co podają media. Wyjątkowe jest organizowanie przez niego zbiórek żywności dla azylu - dla królików w Toruniu. Potrafi zachęcić uczniów nie tylko do przyniesienia siana, ale także innej pomocy dla królików. Wiemy, że jako specjalista od spraw króliczych zawsze podzieli się swoją wiedzą na temat królików ze swoimi uczniami i przychodzimy do niego, gdy mamy problemy takie lub inne" (uczeń LO na temat nauczyciela wiedzy o społeczeństwie).

W kontekście tych refleksji nie sposób nie zacytować słów Macieja Tanasia, który podjął próbę odpowiedzi na pytanie: „po co ludziom potrzebna jest pasja?” Odpowiada na nie w następujący sposób: „po to, by odnaleźli siebie i własną drogę, po to, by żyli w najbardziej humanistycznym sensie tego słowa" (Tanaś, 2015, s. 82). Nauczyciele z pasją pomagają odkryć i rozwinąć swoim uczniom własne zainteresowania. $\mathrm{Z}$ kolei wysoki poziom zaangażowania $\mathrm{w}$ wybrane $\mathrm{z}$ pełnym przekonaniem działanie zapewnia przyjemne odczucia, a przyjemność jest emocjonalnym przejawem ,przepływu” (flow - to stan maksymalnego zaabsorbowania uznawany za jeden z filarów dobrostanu) (Goleman, 2014, s. 33). Ten stan maksymalnego zaangażowania pojawia się w życiu wielu ludzi stosunkowo rzadko. W typowym dniu około 15\% ludzi nie doświadcza go w ogóle. Daniel Goleman uważa, że ,jednym z kluczy pozwalających częściej doznawać maksymalnego zaabsorbowania jest połączenie pracy zawodowej z lubianym zajęciem, jak to bywa u szczęśliwców, którym praca zawodowa sprawia wielką przyjemność (Goleman, 2014, s. 33). Takie osoby, łączące zawód i pasję, stają się autorytetami, gdyż są autentyczni w tym, co robią. Fantastyczne jest to, że takich nauczycieli mogą (choć oczywiście ciągle nie jest to regułą) spotkać na swojej szkolnej drodze uczniowie. Nie sposób zatem nie sięgnąć ponownie do słów W. Okonia: „od osoby nauczyciela zależy powodzenie w jego pracy w tym znaczeniu, że jako swoisty model, stale obserwowany przez uczniów, staje się dla nich wzorem lub antywzorem postępowania. Pożądanym wzorem staje się zwłaszcza wtedy, gdy nie uważając się za nauczyciela doskonałego, stale pracuje nad sobą jako człowiekiem, jako specjalistą, jako pedagogiem, gdy usiłuje kierować się w życiu ideałami prawdy, dobra i piękna, gdy rozumie i lubi swoich wychowanków, gdy respektuje ich podmiotowość oraz usiłuje, jak najlepiej przygotować ich do życia” (Okoń, 1992, s. 135). McLaren dodaje, że „uczniowie nie będą uczyli się niczego „pożytecznego”, jeżeli nauczyciele nie będą potrafili zrozumieć przeróżnych sposobów kształtowania uczniowskich tożsamości i percepcji. Słowem, jeżeli nie zrozumieją, w jaki sposób doświadczenia pochodzą z różnych sfer codziennego życia, wytwarzają różne głosy wykorzystywane 
przez uczniów do nadawania znaczeń swym światom i, co za tym idzie, swemu istnieniu w społeczeństwie" (McLaren, 2015, s. 302). Autor ten zaznacza, że nie wszystkie doświadczenia uczniów zasługują na bezkrytyczną afirmację. Ważne jest, pisze dalej, żeby nauczyciele brali pod uwagę, w jaki sposób uczniowie doświadczają świata społecznego i jak go wytwarzają (McLaren, 2015, s. 302). Nauczyciel musi umieć zrozumieć perspektywę każdego ze swoich uczniów, ponieważ każda będzie inna, każda będzie indywidualna, ale równocześnie każda będzie wartościowa. „W przeciwnym razie nauczyciel nie zdoła dotrzeć do emocji uczniów, ich zainteresowan i „tego, co ich napędza”, co pozwala mówić im własnym głosem" (McLaren, 2015, s. 302). To wiąże się z otwartością nauczyciela na pomysły, zainteresowania i sposób dochodzenia do wiedzy i rozwiązań uczniów. Współczesnej szkole potrzeba więc nauczyciela kreatywnego, będącego jednostką ,świadomie kreatywną i bardzo trudną do wiernego odtworzenia u poszczególnych jednostek" (Bauman, Leoncini, 2018, s. 99). Thomas Leonicini podkreśla, że współcześnie istnieje wiele osób z wysokimi kompetencjami formalnymi, które oczekują od innych, że otrzymają pewien status, jak to bywało w przeszłości, w odniesieniu do tych osób, które miały niższe kwalifikacje formalne.

\section{KSZTAŁCENIE OSOBOWOŚCI NAUCZYCIELI DLA EDUKACJI PRZYSZŁOŚCI}

Nauczyciele, których dzisiaj kształcimy w wyższych uczelniach, będą wychowywać pokolenie ludzi żyjących w XXI i XXII wieku. I choć brzmi to i patetycznie, i banalnie, jednak nie da się pominąć faktu, że to ta właśnie grupa zawodowa dźwiga na swoich barkach odpowiedzialność za przygotowanie do życia pokolenia, które będzie kreowało rzeczywistość w XXII wieku. Spójrzmy na to w ten sposób: jeżeli założymy, że w roku akademickim 2019/2020 przyjmiemy grupę studentów, którzy będą studiować przez pięć lat - skończą pięcioletnie studia w 2024/2025 roku, to oni - będąc czynnymi zawodowo nauczycielami przez kolejnych 40 lat - będą wychowywać pokolenie, którego średnia dorosłość przypadnie na XXII wiek. Nie możemy zatem jednoznacznie określić, jak będzie wyglądał zawód nauczyciela, jaka będzie szkoła w 2065 roku. A to przecież nie tak odległa przyszłość. Zatem kształcenie przyszłych nauczycieli musi być zorientowane nie tylko na jak najwyższą jakość (ocenianą z dzisiejszej perspektywy) i tworzenie bogatej i zróżnicowanej oferty edukacyjnej wpisującej się 
w oczekiwania otoczenia społecznego, a w szczególności zróżnicowanych grup pracodawców, ale musi być kształceniem zorientowanym ku niewiadomej przyszłości. W procesie kształcenia akademickiego należy zatem poszukiwać takich rozwiązań, aby rozwijać u studentów - przyszłych absolwentów kierunków nauczycielskich - zdolności do zdecydowanie humanistycznego podejścia do własnych biografii i rzeczywistości społecznej, a także rozwijania zdolności do krytycznej refleksji i umiejętności samodzielnego dokonywania wyborów życiowych. Tych wyborów będą przecież dokonywali w swoim przyszłym życiu zawodowym, a jakie one będą - tego dziś nie jesteśmy w stanie przewidzieć. Kształcenie nauczycieli musi zatem być, jak już wielokrotnie zaznaczyłam, dostosowane do dynamicznie zmieniających się warunków życia, ale też do zmieniających się potrzeb młodych ludzi. Wychodzić im naprzeciw i dawać możliwość konstruowania indywidualnej ścieżki rozwoju zawodowego. Jesteśmy dziś odpowiedzialni za kształcenie pokolenia, które urodziło się po 1989 roku. Zaś w przyszłym roku akademickim podejmie studia grupa młodych ludzi urodzonych w roku 2000. Kolejne lata to praca nauczycieli akademickich z młodymi ludźmi urodzonymi w XXI wieku, których określa się mianem pokolenia „Z”. Pokolenie, wkraczające dziś w dorosłość, charakteryzowane jest następująco:

- jako pracownicy nie chcą się nudzić;

- pragną zmieniać świat, a przy okazji dobrze zarabiać;

- mają większą wiedzę niż ich rówieśnicy sprzed 20 lat;

- są świadomi swojej wiedzy, a co za tym idzie bardzo pewni siebie;

- mają poczucie własnej wartości;

- są skoncentrowani na sobie;

- nie przywiązują się do miejsca (uczelni, miejsc pracy, zamieszkania);

- znają języki i nie boją się nowych sytuacji i wyzwań;

- to światowi tubylcy - jeśli w Polsce nie znajdą miejsca dla siebie - będą go szukali poza jej granicami;

- posługują się nowymi technologiami;

- trudno im godzić się z porażkami, gdyż nastawieni są na sukces;

- są gotowi i otwarci na wszelkie zmiany.

Trzeba pamiętać, że mamy do czynienia z osobami, które są (choć nie jest to oczywiście regułą):

- jedynymi dziećmi w rodzinie;

- od najmłodszych lat miały możliwość rozwijania licznych talentów i zainteresowań; 
- byli bardzo dobrymi i najlepszymi uczniami w swoich szkołach (podstawowych i średnich);

- wyjechali ze swoich miejscowości, by podjąć studia w różnych ośrodkach kształcących nauczycieli;

- w momencie podjęcia studiów rozpoczęli nowe życie w nieznanym, większym (dużym) mieście;

- rodzina udziela im dużego wsparcia materialnego, choć wielu z nich musi szybko się usamodzielnić podejmując pracę i łącząc aktywność zarobkową ze studiowaniem.

W procesie kształcenia trzeba zatem uwzględniać te cechy i dyspozycje młodego pokolenia.

\section{ROZWIJANIE OSOBOWOŚCI I PASJI PRZYSZŁYCH NAUCZYCIELI - PRZYKŁADY ROZWIĄZAŃ}

Kształcenie i przygotowanie do zawodu nauczyciela powinno zatem odpowiadać zainteresowaniom i potrzebom tych młodych ludzi z uwzględnieniem szerszego kontekstu społecznego. W procesie przygotowania studentów na Wydziale Studiów Edukacyjnych Uniwersytetu im. Adama Mickiewicza w Poznaniu staramy się zwracać uwagę na to, by student mógł być osobą:

- autonomiczną

- aktywną

- kreatywną

- samorządną

- przedsiębiorczą

- dociekliwą

- krytyczną.

Staramy się też rozwijać samorządność i kompetencje liderskie studentów w ramach dwojakiego rodzaju działań:

- obowiązkowych zajęć i praktyk objętych programem studiów;

- aktywności pozaformalnej.

W tej relacji przyjmujemy na siebie role liderów, gdyż doskonale wiemy, że dobry lider - co zaznacza Anna Brzezińska - widzi jednocześnie ludzi i zadania. „Widzi poszczególne osoby, ich potencjał, ale równocześnie ich ograniczenia. Lider potrafi wykorzystać zasoby, które aktualnie są do dyspozycji. Jednocześnie 
osiąganie celu przebiega w sposób sprzyjający rozwojowi ludzi” (Brzezińska, Janiszewska-Rain, 2005, s. 138).

Dostrzegamy i mamy świadomość, że studenci nie chcą się nudzić i potrzebują nieustannie nowych inspiracji. Chcą być aktywni, pragną działać i weryfikować wiedzę i umiejętności w praktycznym działaniu, w określonych zadaniach. Naszą troską jest również to, by nasi absolwenci, po ukończeniu studiów na kierunku pedagogika, stawali się liderami w swoich społecznościach lokalnych, gdyż te cechy pokoleniowe, na które wcześniej wskazałam, stanowią znakomitą bazę do tego, by rozwijali takie kompetencje, które pozwolą im pełnić ważne społecznie role jako nauczyciele edukacji przedszkolnej i wczesnoszkolnej, ale także jako świadomi i odpowiedzialni obywatele. Staramy się więc wspierać kompetencje liderskie młodych ludzi. Skoncentruję zatem swoją uwagę na zaprezentowaniu propozycji działań wybranych spośród bogatej oferty kierowanej w stronę studentów Wydziału Studiów Edukacyjnych. W kilku zdaniach scharakteryzuję projekty, które na stałe wpisały się w kalendarz wydarzeń Wydziału i spróbuję pokazać wartość dodaną - z perspektywy rozwoju kompetencji studentów każdego z tych projektów.

1. Projekt „Studenci UAM bez Granic" to międzynarodowy projekt badawczo-edukacyjny, realizowany przez zespół studentów ${ }^{1}$ działających w Kole Naukowym Edukacji Międzykulturowej. Projekt zapoczątkowano w 2014 roku i do chwili obecnej zrealizowano pięć jego edycji. Jego zasadniczym celem jest poznawanie przez studentów wiedzy o wspieraniu edukacji dzieci z obszaru Globalnego Południa. Zespół projektu (w zmieniającym się składzie) podejmuje działania edukacyjne $w$ szkołach podstawowych wykorzystując inne, niż stosowane tam na co dzień, metody pracy z dziećmi. Studenci proponują uczniom działania oparte na założeniach pedagogiki zabawy, twórczym rozwiązywaniu problemów, na aktywnościach ruchowych, muzycznych, plastycznych, Total Physical Response, z wykorzystaniem Chusty Klanzy, gier dydaktycznych, zestawów Lego Education itp. Tworzą zatem sytuacje, w których uczniowie z miejscowych szkół mogą zdobywać nowe dla nich doświadczenia.

\footnotetext{
${ }^{1} \mathrm{~W}$ projekcie uczestniczą również byłe studentki Wydziału, aktualne jego doktorantki, co stanowi dowód na to, że młodzi ludzie w płynnej rzeczywistości cenią działania, które uznają za wartościowe i są gotowi podejmować wysiłek długoterminowy, potrafią rezygnować z celów krótkoterminowych na rzecz osiągnięcia tego bardziej oddalonego w czasie, są stali i konsekwentni w realizacji swoich pasji i zamierzeń.
} 
Podczas kolejnych edycji projektu, realizowanych w okresie letniej przerwy od zajęć dydaktycznych, studenci odwiedzili: szkoły w Tanzanii (Biharamulo) w 2014 r., szkoły w Paragwaju (San Alberto) w 2015 r., szkoły w Indonezji (Ubud na wyspie Bali) w 2016 r., szkoły w Nepalu (Thansing) w 2017 r. oraz szkoły na Madagaskarze (Ambohidratrimo) w 2018 r.

Ważnym elementem każdej edycji projektu jest pozyskanie budżetu niezbędnego do zakupu potrzebnych materiałów dydaktycznych i przekazanie ich szkołom, w których studenci prowadzą zajęcia. Wolontariusze do tej pory zawieźli do szkół ponad 600 kg materiałów dydaktycznych, które przekazali nauczycielom i uczniom, by służyły w procesie dalszej edukacji. Co ważne materiały, które zawożą do szkół wolontariusze, pozyskują w trakcie całego roku akademickiego. Ich zadaniem jest więc zaangażować do współpracy jak najwięcej darczyńców i osób wspierających projekt. W roku 2018 roku w akcję zatytułowaną przez studentów-wolontariuszy „MADA-WYPRAWKA” na rzecz dzieci ze szkoły Saint Joseph College z Ambohidratrimo na Madagaskarze, znajdującej się pod opieką Fundacji „Ankizy Gasy - Dzieci Madagaskaru”, zaangażowało się ponad 4000 osób z kilkudziesięciu placówek oświatowych z Poznania (i nie tylko) przekazując różne materiały dydaktyczne.

Oprócz zadań edukacyjnych, skierowanych do uczniów szkół podstawowych na terenach wizytowanych, studenci prowadzą badania naukowe zogniskowane wokół tematu marzeń i aspiracji życiowych dzieci w krajach, w których realizowany jest projekt. Wyniki badań są przez nich analizowane, opracowywane i prezentowane np. podczas corocznej konferencji kół naukowych. Wnioski z badań są też wykorzystywane w przygotowaniu kolejnych edycji projektu.

Dodatkowym, aczkolwiek bardzo istotnym celem, realizowanym przy okazji tego projektu, jest upowszechnianie założeń i propagowanie idei edukacji międzykulturowej wśród dzieci i młodzieży ze szkół podstawowych i ponadpodstawowych w Poznaniu i województwie wielkopolskim, szerszej społeczności lokalnej, a także wśród studentów.

Wartość dodana udziału studentów w projekcie:

- Rozwijanie umiejętności realizacji kolejnych etapów działań projektowych (od pomysłu, przez przygotowanie projektu, pozyskanie środków na wyjazd, ewaluację projektu itp.);

- Kształtowanie umiejętności pracy w grupie na różnych etapach wspólnego działania;

- Rozwijanie umiejętności przewidywania różnych możliwych wersji działań dostosowanych do potrzeb uczniów i elastycznego odpowiadania na te potrzeby; 
- Kształtowanie umiejętności elastycznego działania, weryfikowania celów, uwzględniania okoliczności, w których się działa;

- Kształtowanie postawy odpowiedzialności za siebie i innych (kolegów, koleżanki, dzieci, z którymi podejmuje się działania);

- Rozwijanie kompetencji metodycznych;

- Budowanie własnego warsztatu pracy i umiejętności radzenia sobie w nietypowych warunkach przestrzennych, lokalowych itp.;

- Wzbogacanie wiedzy na temat krajów, specyfiki życia mieszkańców, rozumienie potrzeb dzieci z terenów Globalnego Południa;

- Rozwijanie umiejętności profesjonalnego radzenia sobie w sytuacjach, których się wcześniej nie przewidziało, szybkich wniosków i poszukiwania rozwiązań;

- Przekształcanie działań i relacji zorientowanych na krótkoterminowe cele i zadania, zadania i relacje zogniskowane wokół celów powtarzalnych, długoterminowych.

2. Projekt „Przedszkolaki na Uniwersytecie” zorientowany na szerzenie idei współpracy i współdziałania między nauczycielami przedszkoli, rodzicami, dziećmi a studentami i pracownikami wyższej uczelni. To projekt o zasięgu lokalnym aktualnie obejmujący kilkanaście przedszkoli uczestniczących w projekcie i kilkanaście okazjonalnie włączających się we wspólne działania. Jego inicjatorką była studentka specjalności wychowanie przedszkolne i nauczanie początkowe ${ }^{2}$, aktualnie doktorantka na Wydziale. W pierwszej edycji, która rozpoczęła się w 2014 roku i miała na celu bardziej pogłębioną współpracę z jednym przedszkolem. W kolejnej edycji do projektu dołączyły trzy kolejne przedszkola, zaś trzecia edycja objęła swoim zasięgiem aż jedenaście przedszkoli i studentów działających w kilku kołach naukowych.

Każda edycja projektu trwa kilka miesięcy, podczas których realizowane są następujące bloki wspólnych działań:

A. Dzieci na uniwersytecie - dzieci przedszkolne poznają Uniwersytet. Odbywają zajęcia w salach wykładowych, konwersatoryjnych, zwiedzają bibliotekę wydziałową, mają zajęcia w salach sportowych na Campusie Ogrody. Uczestniczą w przedstawieniach, koncertach na terenie Wydziału.

\footnotetext{
${ }^{2}$ Mgr Anna Schmidt jest aktualnie doktorantką na Wydziale i przygotowuje pod moim kierunkiem rozprawę doktorską na temat: „Współpraca na rzecz wspomagania rozwoju dziecka w wieku przedszkolnym".
} 
B. Studenci przedszkolakom - przedszkolaki studentom: studenci przygotowują zajęcia dla dzieci przedszkolnych, które realizują na terenie Wydziału i w przedszkolach.

C. Poznajemy, wiemy, umiemy - studenci poznają specyfikę funkcjonowania przedszkoli projektowych, zapoznają się z dokumentacją, zasobami, projektami realizowanymi $\mathrm{w}$ przedszkolach, poznają nauczycieli i nawiązują z nimi bliższe relacje.

D. Poszerzyć horyzonty - oferta skierowana w stronę nauczycieli oraz wykładowców którzy podczas spotkań warsztatowych, wykładów poszerzają swoją wiedzę i rozwijają kompetencje metodyczne. W roku akademickim 2018/2019 nauczycielom i rodzicom zaproponowano następujące warsztaty i wykłady:

- „Współpraca się opłaca...” - przykłady dobrych praktyk”

- „Dziecko dwujęzyczne w przedszkolu i szkole - przykłady dobrych praktyk”

- „Wspieranie zdolności i zainteresowań dziecka w wieku przedszkolnym. Współpraca na rzecz optymalnego rozwoju"

- Dlaczego nie zawsze jest łatwo? - o komunikacji z rodzicami”

- „Aktywności muzyczne a wzmacnianie więzi z dzieckiem”

- „Dialog z rodzicem - dialog z dzieckiem”.

Wartość dodana udziału studentów w projekcie:

- Podejmowanie zadań ,partnerskiej współpracy” z nauczycielami przedszkoli, innymi studentami, rodzicami dzieci przedszkolnych - uczenie się od siebie nawzajem i rozwijanie kompetencji kooperacyjnych podczas wspólnych zadań z osobami o zróżnicowanym doświadczeniu życiowym i zawodowym;

- Rozwijanie kompetencji potrzebnych do wykonywania przyszłej pracy zawodowej w trakcie przygotowywania, realizacji i ewaluacji warsztatów i zajęć dla dzieci na terenie WSE i w przedszkolach;

- Poznawanie specyfiki zawodu nauczyciela „od kuchni” poprzez możliwość przebywania w placówkach przedszkolnych, udział w warsztatach i szkoleniach adresowanych do nauczycieli, udział w seminariach i dyskusjach poświęconych zagadnieniom edukacji przedszkolnej;

- Rozwijanie umiejętności pracy z różnymi grupami dzieci, o zróżnicowanych potrzebach, możliwościach, zainteresowaniach i doświadczeniach;

- Rozwijanie umiejętności elastycznego reagowania na nieprzewidziane sytuacje i zmieniający się kontekst działania;

- Przekształcanie działań i relacji zorientowanych na krótkoterminowe cele i zadania w cele, zadania i relacje zogniskowane wokół celów powtarzalnych, długoterminowych. 
3. Projekt „Dzień Rodziny Szamarzewo” to inicjatywa o zasięgu lokalnym skierowana do środowiska lokalnego - okolic Campusu Ogrody, na którym mieści się Wydział Studiów Edukacyjnych oraz dzieci z przedszkoli i szkół współpracujących z Wydziałem. Wydarzenie ma charakter festynu rodzinnego i realizowane jest od 2014 roku w czerwcu na terenach zielonych Campusu Ogrody UAM. Studenci przygotowują program wydarzenia, odpowiadają za jego organizację, logistykę i bezpieczeństwo zaproszonych osób.

Wartość dodana udziału studentów w projekcie:

- Rozwijanie umiejętności planowania i organizacji wydarzeń kulturalno-rozrywkowych adresowanych do osób w różnym wieku - w wydarzeniu uczestniczą rodziny z dziećmi w różnym wieku;

- Kształtowanie kompetencji związanych z przewidywaniem różnych możliwych scenariuszy i wersji wydarzenia;

- Kształtowanie umiejętności pracy w zespole, dzielenie się zadaniami, przyjmowanie i ponoszenie odpowiedzialności za podjęte zobowiązania;

- Rozwijanie umiejętności profesjonalnego reagowania na potrzeby osób uczestniczących w wydarzeniu i uwzględniania szerszego kontekstu sytuacyjnego (pogoda, zmienna liczba uczestników, dzieci w różnym wieku itp.);

- Rozwijanie kompetencji łączenia wiedzy i praktycznego działania.

4. Festiwal Kultury Studentów „Kulminacje” - to święto kultury studentów, oficjalnie dwudniowe, w praktyce wydarzenia trwają przez cały tydzień maja. To okazja dla studentów, by podzielić się z innymi swoimi pasjami i zarazić innych tym, co prawdziwie inspiruje. Studenci Wydziału są organizatorami warsztatów, wykładów, wystaw, przedstawień teatralnych, koncertów, eventów. Drugi dzień Festiwalu przeznaczony jest na konferencję kół naukowych. W roku akademickim 2017/2018 podczas IX Festiwalu Kultury Studentów odbyła się X Konferencja Kół Naukowych zatytułowana: „Między radością a cierpieniem. Wyzwania współczesnej pedagogiki”. Podczas konferencji członkowie kół naukowych mają okazję, by rozpowszechniać rezultaty prowadzonych przez nich badań, dzielić się doświadczeniami praktycznymi. Podczas prowadzonych warsztatów prezentują pewne propozycje rozwiązań, które mogą zostać wykorzystane w praktyce edukacyjnej.

Wartość dodana udziału studentów w projekcie:

- Kształtowanie poczucia wspólnotowości i orientacji na wspólny cel, wspólne zadanie (przygotowania do wydarzenia trwają kilka miesięcy i angażują wielu studentów w ramach różnorodnych działań); 
- Rozwijanie wrażliwości na różne formy wyrazu artystycznego dzięki możliwości udziału w koncertach, przedstawieniach teatralnych, wystawach;

- Dzielenie się z innymi osobami swoimi zainteresowaniami, pasjami, tym, co inspiruje do własnej twórczości plastycznej, ruchowej, teatralnej;

- Możliwość zaprezentowania własnych wytworów: prac plastycznych, instalacji, kompozycji, przedstawień itp;

- Kształtowanie umiejętności profesjonalnego przygotowania, wygłoszenia, prezentacji podczas konferencji naukowej;

- Rozwijanie kompetencji organizacyjnych związanych z przygotowaniem i przeprowadzeniem warsztatów dla grup studentów;

- Rozwijanie umiejętności podejmowania zobowiązań i ponoszenia odpowiedzialności;

- Przekształcanie działań i relacji zorientowanych na krótkoterminowe cele i zadania w cele, zadania i relacje zogniskowane wokół celów powtarzalnych, długoterminowych.

Podejmując i realizując każde z tych przedsięwzięć studenci poszerzają swoje kompetencje, a zespoły, które współtworzą ,,dysponują coraz większą gamą możliwości" (Brzezińska, Janiszewska-Rain, 2005, s. 139), które będą przydatne w kolejnych wspólnie podejmowanych działaniach.

\section{PODSUMOWANIE}

Podsumowując swoje rozważania powtórzę, za Zdzisławem Bartkowiczem, iż nauczyciel najbliższych dziesięcioleci będzie taki, jakim go teraz przygotujemy do tej roli. Bez przesady można powiedzieć, że to my jesteśmy współodpowiedzialni za polską szkołę, gdyż uczestniczymy w przygotowaniach nauczyciela, który jutro będzie w dużej mierze o niej decydował" (Bartkowicz, 2007, s. 28). Dokładajmy zatem starań, aby kształcenie akademickie było dla młodych ludzi wielką przygodą i doświadczeniem, którym będą chcieli dzielić się ze swoimi przyszłymi uczniami.

\section{BIBLIOGRAFIA}

BARTKOWICZ, Z. (2007). Nauczyciel kompetentny w perspektywie deontologicznej. W: BARTKOWicz Z., Kowaluk M., SAMujŁo (red.), Nauczyciel kompetentny. Teraźniejszość i przyszłość. Lublin: UMCS

Bauman, Z (2007). Płynne życie. Kraków: Wydawnictwo Literackie. 
BAUMAn, Z. (2009). Konsumowanie życia. Kraków: Wydawnictwo Uniwersytetu Jagiellońskiego. BrożeK, B. (2017). Myślenie. Podręcznik użytkownika. Kraków: Copernicus Center Press. BRUNER, J. (2010). Kultura edukacji. Kraków: Universitas.

BRZEZIŃSKA, A., JANISZEWSKA-RAIN, J. (2005). W poszukiwaniu złotego środka. Rozmowy o rozwoju człowieka. Kraków: Znak.

Dryden, G., Vos, J. (2003). Rewolucja w uczeniu. Poznań: Zysk i S-ka.

DUDZIKOWA, M., NOWAK, M. (red.) (2015). O pasjach cudzych i wtasnych - profesorowie. Lublin: KUL.

Goleman, D. (2014). Focus. Sztuka koncentracji jako ukryte dążenie do doskonatości. Poznań: Media Rodzina.

HejnicKA-BeZwińskA, T. (2008). Pedagogika ogólna. Warszawa: Wydawnictwo Akademickie i Profesjonalne.

KorczaK, J. (2017). Prawo dziecka do szacunku. Warszawa: Biuro Rzecznika Praw Dziecka.

KuPISIEwICZ, Cz. (2012). Dydaktyka. Podręcznik akademicki. Gdańsk: Impuls.

OкоŃ, W. (1992). Stownik Pedagogiczny. Warszawa: PWN.

MCLAREN, P. (2015). Życie w szkołach. Wprowadzenie do krytyki pedagogicznej. Wrocław: Wydawnictwo Naukowe Dolnośląskiej Szkoły Wyższej.

SPECK, O. (2005). Być nauczycielem. Gdańsk: Gdańskie Wydawnictwo Psychologiczne.

ŚRODA, M. Edukacja w XXI wieku, www.kongreskobiet.pl/Content/uploaded/files/CAiE\%20i\%20 Media/02_Edukacja\%20XXI-Raport.pdf - [dostęp: 7.01.2019].

SZYMAŃSKI, M.J. (2008). Funkcje edukacji szkolnej w zmieniającym się społeczeństwie. W: B. MUCHACKA, M. SZYMAŃSKI (red.), Szkoła w świecie wspótczesnym. Kraków: Impuls.

TANAŚ, M. (2015). Po co ludziom potrzebna jest pasja? Perspektywa bio- i doksograficzna. W: M. DUDZIKOWA, M . NOWAK (red.), O pasjach cudzych $i$ wtasnych - profesorowie. Lublin: KUL.

\title{
ROZWIJANIE OSOBOWOŚCI I PASJI NAUCZYCIELI W PŁYNNEJ RZECZYWISTOŚCI XXI WIEKU - POSZUKIWANIE ROZWIĄZAŃ
}

\author{
Streszczenie
}

$\mathrm{W}$ artykule poruszono zagadnienie poszukiwania rozwiązań związanych z uniwersyteckim kształceniem nauczycieli edukacji przedszkolnej i wczesnoszkolnej w dobie intensywnych i nieprzewidywalnych zmian. Płynna rzeczywistość, w której funkcjonujemy, stawia przed osobami odpowiedzialnymi za kształcenie nauczycieli ważne zadanie - przygotowanie ich do radzenia sobie z nieustannymi zmianami i otwartości na zachodzące zmiany. W rzeczywistości, która się nieustannie zmienia, trudno jest przewidzieć, jakie kompetencje będą potrzebne nauczycielom w kolejnych dziesięcioleciach XXI wieku. Z całą pewnością warto skoncentrować działania na wspieraniu pasji i rozwijaniu cech osobowościowych przyszłych nauczycieli pracujących z dzieckiem w wieku przedszkolnym i wczesnoszkolnym. W procesie kształcenia trzeba też mieć na uwadze potrzeby i oczekiwania młodego pokolenia przyszłych nauczycieli, którzy reprezentują pokolenie określane w literaturze mianem pokolenia ,Z”. W artykule, oprócz rozważań teoretycznych, podjęto próbę pokazania wybranych rozwiązań wypracowanych na Wydziale Studiów Edukacyjnych Uniwersytetu im. Adama Mickiewicza w Poznaniu.

Słowa kluczowe: kształcenie nauczycieli; kształcenie uniwersyteckie; kompetencje nauczycieli; osobowość; pasja; edukacja przedszkolna i wczesnoszkolna. 


\title{
DEVELOPING TEACHERS' PERSONALITIES AND PASSION \\ IN THE FLUID REALITY OF THE $21^{\text {ST }}$ CENTURY \\ - SEARCHING FOR SOLUTIONS
}

\begin{abstract}
S u m m a ry
The article discusses searching for solutions related to the university education of preschool and early school teachers in a time marked by intense and unpredictable changes. The fluid reality we live in poses an important challenge for those responsible for teacher training, requiring them to prepare teachers to deal with constant changes and remain open to what is yet to come. In a constantly changing reality, it is difficult to predict which competencies teachers will need in the next decades of the $21^{\text {st }}$ century. It is certainly worth the effort to focus on fostering the passion and developing the personalities of future teachers working with children of preschool and early school age. The education process should also take into account the needs and expectations of the new generation of teachers, representing what the literature of the subject describes as "generation Z". Apart from including theoretical considerations, the article is an attempt to showcase selected solutions developed at the Faculty of Educational Studies of Adam Mickiewicz University in Poznan.
\end{abstract}

Key words: teacher education; university education; teacher competencies; personality; passion; preschool and early school education. 